National Museum of Wales and the Press Board of the University of Wales, 1940. 5s.). Like its two predecessors dealing with the botany of Wales, published by the Museum, it is a most useful volume, and both text and illustrations leave little to be desired. The introduction conveys all that the student needs to understand the fern's life-history, and in the more detailed descriptive portion the keys and descriptions, aided by the clear text figures skilfully drawn by Miss E. A. Jenkins, should enable anyone to identify and discover all there is of interest in our native ferns. Now that so many name changes have taken place, one would have welcomed the inclusion of some of the old names-now synonyms-with which older botanists are more familiar.

\section{Utilization of Sun Power}

Generation of electrical energy direct from the sun's rays has been feasible for many years, but in most cases the price is quite prohibitive. Up to a few years ago, such installations took up so much space and required such a high expenditure per horsepower on apparatus that projects suggested were not inviting. Most engineers took this view and regarded them as only of academic interest. Recent advances in the treatment of aluminium, in vacuum jacketing, in flash boilers and in mechanism for following the sun on its daily course have put a different aspect on the problem of solar steam-raising plant. Dr. C. G. Abbot, secretary of the Smithsonian Institution, Washington, D.C., who is well known for his solar investigations; now states in the course of an article covering some six pages (J. Amer. Inst. Elect. Eng.) that power from the sun can be obtained at 0.5 cent per h.p., which is the pre-War equivalent of one farthing. He estimates that at this price such schemes can give a good return on invest. ment. Even if we apply the corrective factor which is usually necessary in estimates by enthusiasts and raise the farthing to $\frac{1}{2} \mathrm{~d}$. or $\frac{3}{4} d$., sun-power is obviously becoming a business for hot climates, and developments are worth watching.

\section{Health of New Zealand}

According to the Director-General of Health, in 1939 the death-rate of New Zealand with a population of a little more than $1,500,000$ (including 80,000 Maoris) was $9 \cdot 20$ per 1,000 population (excluding the Maoris) and the infantile mortality (with the same exclusion) $31 \cdot 14$ per 1,000 live births. The birth-rate was $18 \cdot 73$ per 1,000 of population. Heart disease was the principal cause of death, and cancer, from which there were 1,815 deaths, came next. The incidence of infectious diseases was low, but their notification among the Maoris had increased. The nutrition of the majority of school children was satisfactory, but there was still some evidence of subnormal nutrition. Maternal deaths due to pregnancy or childbirth other than deaths from septic abortion numbered 85 , a death-rate of 2.95 per 1,000 births, as compared with $2 \cdot 80$ for England and Wales in 1938. There were 147 cases of puerperal sepsis notified. The rise in the number of deaths due to this cause has been attributed to the wrongful use of sulphonamides resulting in a granulocytosis. The maternal mortality among the Maori women, a large number of whom are still delivered by native methods, was $4 \cdot 13$ as compared with $5 \cdot 41$ the previous year.

\section{Health on Gibraltar}

THE report for 1939 of Major R. A. Mansell, the medical officer of health of Gibraltar, of which a summary appears in the British Medical Journal of November 2, states that among the civilian population the birth-rate was 20.85 per 1,000 and the death-rate 14.25, which were both larger than in most English towns. The infantile mortality, which has been rising steadily in recent years in association with gross overcrowding, was last year $79 \cdot 36$ per 1,000 births and was the highest since 1928. On the other hand, Gibraltar has been singularly free from epidemic disease. During the year there were only 93 cases of notifiable infectious diseases, the lowest number for half a century, and more than a third of these were chicken-pox. There were ten deaths from pulmonary tuberculosis, the prevalence of which is causing the medical officer some disquiet.

\section{Bibliography of Seismology}

The Bibliography of Seismology, covering ninetyeight items for the period. April, May, June 1940, published by the Dominion Observatory at Ottawa and compiled by Ernest A. Hodgson, has just been received. It is an invaluable reference work and contains items from most countries concerning studies of individual earthquakes, seismological apparatus, seismic prospecting, rock bursts, travel-time tables, tunamis, and many kindred subjects. A list of six patents for apparatus chiefly in connexion with seismic surveying is listed. All are American patents. References are given to seismological and geophysical publications in the Proceedings of the Royal Society, in NATURE, in the Geophysical Supplement of the Royal Astronomical Society and other British periodicals.

\section{Announcements}

IT was announced in the London Gazette of December 3 that the King has approved the award of the George Cross to Dr. A. D. Merriman, part-time experimental officer in the Directorate of Scientific Research, Ministry of Supply, "for conspicuous bravery in connexion with bomb disposal."

By German decree the University of Leyden and the Technical High School at Delft have been closed owing to the "generally anti-German attitude of the undergraduates, and sabotage of the anti-Jewish measures". All professors of the Faculty of Laws of the University of Utrecht have been sent to concentration camps in Germany, while several professors of the Catholic University at Nijmegen, and of the Commercial High School at Rotterdam, have been arrested because of their loyalty to the House of Orange and openly admitted preference for a democratic system of government. A number of students at all these institutions have been arrested, fined, or sent to concentration camps. 